\title{
Illumination and mood
}

\section{Daniel Kripke}

Received: 20 September 2010 / Accepted: 30 September 2010 /Published online: 16 October 2010

(C) The Author(s) 2010. This article is published with open access at Springerlink.com

Hoaki and colleagues recently showed that hyperthermic temperament was strongly associated with increased illumination among a group of healthy subjects. This is interesting because it broadens the context of case reports suggesting that bright light may at times trigger hypomania or mania.

There have been several studies which have suggested a converse relationship that low illumination is associated with depression. I wonder if an association of low illumination and depression was also found in this sample.

Open Access This article is distributed under the terms of the Creative Commons Attribution Noncommercial License which permits any noncommercial use, distribution, and reproduction in any medium, provided the original author(s) and source are credited. 